Vol. 5 No. 1, January 2021, pp. 58-71

\title{
Establishing a Regional-Owned Limited Liability Company: Would it Support an Integrated Tourism Management in Bali?
}

\author{
Luh Ayu Nadira Saraswati* \\ EMERHUB, Market Entry Consultant, Bali-Indonesia
}

Anak Agung Gede Duwira Hadi Santosa ${ }^{* *}$

Faculty of Law, Udayana University, Bali-Indonesia

\begin{abstract}
The rapid development of tourism in Bali has made this sector becomes the main pillar of the economy. Facts indicate that the tourism industry in Bali is not parallel with the equal distribution, which entails an imbalance in both tourism facilities and tourism management. This has an impact on chaotic tourism management: many tourist destinations and attractions were not managed properly and could not develop their potency optimally. This situation reflects an urgency to conceive an integrated tourism development and management. The Bali Provincial Government has addressed this issue by launching the concept of One Island One Management. This paper aims to analyze the tourism management arrangements in Bali with the various challenges faced in its application and to assess the establishment of Regional-Owned Limited Liability Company in realizing the concept of an integrated tourism management in Bali. In terms of writing methodology, this paper applies a normative legal research. The result suggested that a regional-owned limited liability company (LLC) can support the realization of an integrated tourism management in Bali. From a legal perspective, a regional-owned $L L C$ is subject to the company law, which entails that it will strengthen the professionalism in managerial aspects and also will accommodate the participation of the region through the shareholder forum.
\end{abstract}

Keywords: Regional-owned enterprises; Limited liability company; Integrated tourism management; Bali.

\section{INTRODUCTION}

\subsection{Background}

Tourism has continuously become the driving force of Bali's economy that significantly contributed to the locally-generated revenue of the local governments. The rapid development of tourism in Bali began in the 1970s and then continued in the following years. Bali has increasingly established its position as a popular destination in the world. In line with the economic growth, the intensify in tourism activity is supported by the increase of per capita expenses. Furthermore, information technology development and

\footnotetext{
${ }^{* *}$ Email/Corresponding Author: nadira@emerhub.com

${ }^{* *}$ Email : agung_santosa@unud.ac.id
} 
transportation supported the growth of accessibility of tourism in the destination. 1

The development of international-class tourist accommodation facilities has begun by the development of the Nusa Dua area in South Bali into a luxury tourist resort area managed by a state-owned enterprise, namely the Bali Tourism Development Corporation (BTDC). The company was strongly supported by a conducive climate and synergy with the surrounding community, local government, and environmental carrying capacity. 2 The creation of exclusive and prestigious tourism areas has a positive impact on the community, such as creating job opportunities, generating income, and increasing the quality of the environment. ${ }^{3}$ high investment in the Nusa Dua area boosted the development of Bali tourism in general.

The success of Nusa Dua resorts stimulated the development of tourist accommodation in other areas in Bali. In controlling this development, the Bali Provincial Government designated 15 tourist residential areas along with supporting facilities such as restaurants and shopping centers. Until now, Bali has more than 35,000 hotel rooms consisting of cottages, budget hotels, and star hotels. The type of tourist accommodation is also developed such as guest houses, villas, bungalows, and boutique hotels with selling price variations. This diversity gives added value to Bali because it offers tourists many choices. ${ }^{4}$ Various supporting facilities such as restaurants, art shops/markets, entertainment facilities, and recreation have grown rapidly in tourist residential areas.

Tourism development has also an unexpected impact on the local peoples. There are around 75 holy places (Hindu temples in Bali) used as tourist objects and attractions. Likewise, locally-believed sacred objects were profaned and transformed into tourism products. ${ }^{5}$ Tourism development has also endangered the preservation of the natural environment. Further, the development of some tourist accommodations seems to violate the law and regulations such as building permits and environmental impact analysis that threaten the sustainability of the ecosystem. Tourism is still considered as an effective stimulus for development, although the good purposes of development goals are often breached in its process. 6 This situation demands tourism destination management planning and organizations on

1 Gusti Kade Sutawa. "Issues on Bali Tourism Development and Community Empowerment to Support Sustainable Tourism Development." Procedia Economics and Finance 4, (2012): 414.

2 Ida Ayu Kade Werdika Damayanti. "Effectiveness of The Implementation of Corporate Social Responsibility By Star Hotels in Nusa Dua Area to Improve the Environmental Quality and Community Welfare." Atlantis Press: Advances in Social Science, Education and Humanities Research 226 (2018): 496.

3 Ibid.

4 Badan Pembinaan Hukum Nasional "Pembentukan Otonomi Khusus Bali dan Pengaruhnya bagi Keutuhan NKRI". http://www.bphn.go.id/data/documents/lit-20115.pdf, 74 .

5 Ibid.

6 Richard Sharpley. "Tourism and Sustainable Development: Exploring the Theoretical Divide." Journal of Sustainable Tourism 8, no. 1 (2000): 11. 
regional and national scales. The planning should contain four basic tourism assets, namely natural tourism, historical tourism, cultural tourism, and a region's human tourism on a local and national level. ${ }^{7}$

The development of tourism seems to be not optimal in paying attention to local cultural values (local wisdom). Providing the sustainability of the tourism sector, which has a very fragile structure, is related to how many people perceive the economic, socio-cultural, and environmental effects that arise from the tourism activities and their satisfaction with this situation. Sustainable tourism development in destinations is in question due to the lack of consideration $s$ on positive and negative effects arising from the local community and tourism development. 8 Therefore, it is urgent to develop a tourism regional-owned enterprise to ensure the proper management of the tourism industry.

This article discussed two issues. First, how to regulate tourism management in Bali with the various challenges faced in its application. Second, it discusses whether the establishment of a regional-owned enterprise would realize the concept of an integrated tourism management in Bali. It aims to analyze the tourism management arrangements in Bali with the various challenges faced in its application and to assess the establishment of Regional-Owned Limited Liability Company in realizing the concept of an integrated tourism management in Bali. This research is expected to contribute to the evaluation of the Bali Provincial Regional LongTerm Development Plan and Bali Provincial Regional Medium-Term Development. This paper is normative legal research that uses a statutory approach that examining primary and secondary legal materials. The legal materials are collected by using document study techniques while the analysis is presented qualitatively.

\section{RESULT AND ANALYSIS}

\subsection{Tourism Management Arrangements in Bali}

\subsubsection{Tourism Management Arrangements in the Bali Provincial Regional Long and Medium Terms Development Plan}

The direction of various industrial sectors development in Bali is expressly regulated in the Bali Provincial Regulation No. 6 of 2009 concerning Bali Provincial Regional Long-Term Development Plan (hereinafter, Bali Province Long-Term Development Plan) and the Bali Provincial Regulation No. 3 of 2019 concerning the Bali Provincial Regional Medium Term Development Plan Semesta Berencana 2018-2023 (hereinafter, Bali Province Medium-Term Development Plan).

7 Duran Cankül \& Rahman Temizkan. "The Meaning of Tourism Degrees Without Law of Tourism Jobs." Journal of Recreation and Tourism Research 6, no. 4 (2019): 504.

8 Abdullah Uslu, Gurkan Alagoz, \& Erkan Güneş. "Socio-cultural, Economic, and Environmental Effects of Tourism from the Point of View of the Local Community." Journal of Tourism and Services 21, no. 11 (2020): 2. 
Reflecting the dynamic resilience of Bali's culture, 9 Bali Province Long-Term Development Plan stated that cultural tourism is developed sustainably by increasing the involvement of local communities in planning, implementation, and supervision stages. It also implies a tendency to improve community welfare for encouraging competitiveness and the quality of the regional economy. The Bali Province Long-Term Development Plan underlines that the strengthening of regional, national and global competitiveness, industrial policies requires an integrated trade and investment policies by virtue of harmonizing their interrelated interests. ${ }^{10}$

There seems to an efforts to use the benefits of tourism not only to regional development but also to national development. Tourism, and related sectors, had contributed significantly to the formation of the regional GDP and foreign exchange earnings. ${ }^{11}$

Tourism development in Bali indicates a collaborative effort between external and local stakeholders. It provides an interesting example of processes of globalization in the sense that both parties played their specific role in initiating and developing tourism. This can be seen through milestones of stages of Bali tourism development. ${ }^{12}$ As outlined in the Bali Province Medium Term Development Plan, the main focus of Balinese development includes efforts and strategies to maintain harmony and sanctity of nature, people, and Balinese culture in facing local, national, and international challenges and problems. This Medium Term Development Plan uses a unified regional approach namely one island, one pattern, and one governance.

The Bali Province Medium Term Development Plan is based on the Tri Hita Karana philosophy which is further elaborated and operationalized in Sad Kerthi's local wisdom, including: efforts to purify the soul (atma kerthi), preserve forests (wana kerthi) and lakes (danu kerthi) as sources of clean water, the sea and the coast (segara kerthi), dynamic social and natural harmony (jagat kerthi), and building the quality of human resources individually and collectively (jana kerthi). ${ }^{13}$ The plan is implemented with a political, technocratic, participatory, top-down, and bottom-up approach to achieve effective and efficient governance.

The island of Bali, which is relatively small in terms of its area, is very potential to be self-reliantly managed under integrated management. The roles of government as stakeholders are to provide policies and site plans

9 Michel Picard, "Cultural Tourism in Bali: Cultural Performances as Tourist Attraction," Cornell University Press: Indonesia 49 (1990): 37.

10 Bali Provincial Regulation No. 6 of 2009 Concerning The Long Term Development Plan (RPJPD) Bali Province, 2005-2025, Art.4.

11 Made Antara \& Made Sri Sumarniasih. "Role of Tourism in Economy of Bali and Indonesia" Journal of Tourism and Hospitality Management 5, no. 2 (2017): 40.

12 I Nyoman Darma Putra, "Localizing the Global and Globalizing the Local: Opportunities and Challenges in Bali Island Tourism Development," Jurnal Kajian Bali 3, no. 2 (2013): 122 .

13 Bali Provincial Regulation No. 3 Year 2019 concerning The Middle Term Development Plan for The Semesta Region Planning Bali Province 2018-2023, Elucidation 
and other planning documents, and function as a regulator. ${ }^{14}$ In terms of administration, the Province of Bali consists of eight regencies and one city. The government at both provincial level and regency/city level are entitled to create and implement their own regional regulations and policies. After political reform that enlarges the regional autonomy, tourism management seems to be out of control and goes too far. Currently, each regency and city apply different tourist destination management, besides management performed at the provincial level. It is obvious that regency/city created its own management without fully taking into consideration or referring to the provincial policies. Therefore, tourism in Bali is managed by a variety of tourism destination management, namely nine destination management in regencies and city and one in the province. Moreover, national-based agencies responsible for immigration, environment, and security affairs also implement tourism-related management in the region.

\subsubsection{Bali Tourism Policy Evaluation Prior to One Island One Management Policy}

Bali is an international brand due to awards given as the best destination in the world. Behind the development of tourism that is so industrialized there are major problems behind it.15 One of them is the concern on balancing the spread of tourism development in all regions in Bali. The idea of 'One Island, One Management' is aimed to minimize the gap of tourism development between regencies and city. The expected paradigm is strengthening the position Governor of Bali in tourism management as well as granting him a special authority to impose sanctions on the head of regencies/cities for the violations of regulation in concern.

Another problem currently faced in Bali tourism development is spatial planning. The adjustment of the Regional Spatial Plan (Rencana Tata Ruang Wilayah/RTRW) of Bali Province is urgently needed to create a dynamic space in an integrated environmental system based on Balinese culture that is imbued with Hinduism while maintaining environmental sustainability in accordance with the Tri Hita Karana (THK) philosophy. THK is a philosophy that underlies Balinese people in fostering harmonious relationships with God, with fellow human beings, and with the environment. ${ }^{16}$ This inline with a global paradigm - sustainable development - which is suitable for a local society that has developed a very different

14 I Wayan Budiasa \& I Gusti Agung Ayu Ambarawati, "Community Based Agrotourism as an Innovative Integrated Farming System Development Model Towards Sustainable Agriculture and Tourism in Bali," Journal of the International Society for Southeast Asian Agricultural Sciences 20, no. 1 (2014): 35.

${ }^{15}$ I G Mudana, I B P Suamba, I M A Putra \& N W Ardini, "Practices of Bali Tourism Development, Threefolding, and Tri Hita Karana Local Knowledge in New Order Indonesia," Journal of Physics: Conference Series, no. 2 (2017): 1.

16 I Gusti Ayu Agung Omika Dewi, "Culture of Tri Hita Karana on Ease of Use Perception and Use of Accounting Information System," International Journal of Social Sciences and Humanities 2, no. 2 (2018): 78. 
concept of the social and natural environment. ${ }^{17}$ Several related comparative advantage attributes are critical to the development of sustainable tourism destinations, including climate, location, natural resources, tourism awareness among local citizens, and indigenous culture. ${ }^{18}$

Seeing the potential for tourism that can contribute to regional development, the government consciously and continuously develops tourist objects and attractions. Each regency/city in Bali arranges and improves objects or areas that are considered potential as tourist destinations. However, the rate of tourism development still needs improvement, because it is not prepared by a clear planning pattern. The unclear spatial planning has an ecological consequence that would affect the surrounding community and may become a backfire the tourism development in the future. Meanwhile, the development process also puts the involvement and participation of the community in a strategic position. ${ }^{19}$ Therefore, a concept to realize integrated tourism management in Bali is indeed needed.

\subsection{Establishing a Regional-Owned Limited Liability Company to Realize an Integrated Tourism Management in Bali}

\subsubsection{The Purpose of Establishing a Tourism Regional-Owned Enterprise}

Tourism development in Bali must lead to a sustainable tourism development that is reflected in a policy that protects and enhances the natural, social, and cultural resources. Besides, most, if not all, sectors of the tourism industry have a vested interest in following such a policy. 20 Sustainable tourism development also requires 'the adoption of a new social paradigm relevant to sustainable living; herein lies what is, arguably, the greatest challenge to its achievement. ${ }^{21}$

This paper argues that a tourism regional-owned enterprise would make an effort to encourage regional development. It may be designed as a pioneer in the tourism business sector that is not yet attractive to the private sector. Besides, the tourism regional-owned enterprise may become a driving force for the economy in the region because it aims at providing benefits for local economic development, providing public services, and making profits. ${ }^{22}$ It is also expected to provide quality goods and services for

17 Sylvine Picker Chevalier \& Ketut Budarma, "Towards sustainable tourism in Bali: A Western paradigm in the face of Balinese cultural uniqueness," Mondes du Tourisme, no. 1 (2016): 2 .

18 Salah Hassan, "Determinants of Market Competitiveness in an Environmentally Sustainable Tourism Industry," Journal of Travel Research 38, no. 3 (2000): 240.

19 I Made Sudjana, I Komang Gde Bendesa \& Agung Suryawan Wiranatha, "Sanur Area Development Strategy Towards Green Tourism Destination," David Publishing: Management Studies 7, no. 5 (2019): 428.

20 M. Wheeler., "Applying ethics to the tourism industry," Business Ethics, the Environment \& Responsibility 1, no. 4 (1992): 228.

21 V. Middleton and R. Hawkins. Practical Environmental Policies in Travel and Tourism - Part I: The Hotel Sector. (Travel and Tourism Analyst 6, 1993), 65.

22 Nazaruddin Lathif, Mustika Mega Wijaya, \& Raden Muhammad Mihradi, "Changes in the Legal Agency Status of the Pakuan Bogor Regional Legal Company in 
the fulfillment of the people's needs according to the regional characteristics and potency. ${ }^{23}$

To achieve this goal, the management of regional-owned enterprises must apply good corporate governance. ${ }^{24}$ Besides, it must be able to carry out its duties as implementers of public services, especially in the economic field, to balance market forces, and participate in helping the development of small and medium enterprises. ${ }^{25}$ This expectation seems to be realized with the support from existing laws and regulations

\subsubsection{The Legal Form of the Tourism Regional-Owned Enterprises}

As a solution to realize the concept of integrated tourism management in Bali, the establishment of the regional-owned enterprise should be formed in what so-called a Regional-Owned Limited Liability Company (hereinafter Regional-Owned LLC). The Regional-Owned LLC conducts business that providing goods and/or services in high quality and strong competitiveness for both domestic and international markets. Thus, it can increase the profit and value of the company. ${ }^{26}$

Referring to the legislation, the Regional-Owned LLC in its operations is subject to LLC Law, because it can be classified as an independent entity with the following characteristics:

1. The liability arising is borne solely on the assets collected in the association. This is related to the company's status as a legal entity which is considered a separate legal subject apart from individuals, where the liability in an LLC will only be limited to the paid-up capital.

2. The nature of mobility over participation rights, namely the freedom of each shareholder to take part in an LLC. This participation is realized through the form of a stock institution, which aims to maintain the stability of the accumulated capital.

3. The management principle of an LLC in accordance with the provisions of the applicable laws and regulations is carried out by an organ, where this provision means that the later management

Improving Drinking Water Services in Bogor City based on Government Regulation Number 54 of 2017 Concerning Local Government Owned Enterprises (BUMD)," International Journal of Multicultural and Multireligious Understanding 8, no. 1 (2021): 125.

${ }^{23}$ Maskun Suwardi, P. Eko Prasetyo, "Efisiensi Teknis Badan Usaha Milik Daerah (BUMD) Bidang Jasa Produksi Provinsi Jawa Tengah," Jurnal Ekonomi \& Studi Pembangunan 19, no 1 (2018): 11.

24 Darwin Nasution, "Urgency of Local-Owned Enterprises (BUMD) Law as Good Corporate Governance Basis in Indonesia," Atlantis Press: Advances in Social Science, Education and Humanities Research (ASSEHR) 141, (2017): 117.

${ }^{25}$ Adji Suradji Muhammad, Irman, Asmaul Husna \& Eka Suswaini, "Re-organisasi Badan Usaha Milik Daerah: Upaya Meningkatan Kemandirian Daerah," Jurnal Ilmu Administrasi: Media Pengembangan Mmu dan Praktek Administrasi 17, no. 1 (2020): 36.

26Fauzi Syam, Elita Rahmi \& Arsyad, "Eksistensi dan Konstruksi Yuridis Badan Usaha Milik Daerah Pasca Undang-Undang Pemerintahan Daerah Tahun 2014," Undang Jurnal Hukum: Fakultas Hukum Universitas Jambi 1, no. 2 (2018): 305. 
cannot be carried out by shareholders, but by an independent institution whose position is separate as a shareholder. The organs in an LLC according to the Company Law consist of the General Meeting of Shareholders (GMS), the Board of Directors, and the Board of Commissioners which then carry out the activities covering the functions of policymaking, implementation, and supervision. ${ }^{27}$

It is generally conceived that a legal entity applies separation of assets obtained from authorized capital and paid-up capital as the LLC's responsibility as a legal entity. LLC's main interest is to obtain profits that also reflecting the interests of the shareholders. But an LLC has to ensure that its business activities are not in conflict with the laws and regulations, public order, and/or morality.

Regional governments, in carrying out activities in the strategic business sector related to the livelihoods of many people, have to prioritize the benefit to the community. This means that the paradigm of benefits obtained is the implementation of optimal public services. In other words, Regional-Owned Enterprise is considered to be profitable if has been given public benefits to be enjoyed by many people. ${ }^{28}$

The target of establishing Tourism Regional State-Owned Enterprise refers to Article 331 paragraph (4) of Law No. 23 of 2014 concerning Regional Government and Article 7 of Government Regulation No.54 of 2017 concerning Regional Owned Enterprise. Whereas the objectives of establishing the Regional -Owned Enterprise are to:

a. provide benefits for regional economic development;

b. providing public benefits in the form of providing quality goods and/or services to fulfill the livelihood of the community according to the conditions, characteristics, and potential of the area concerned based on good corporate governance; and

c. earn profits. Profits of Regional -Owned Enterprise are a source of regional income that is very useful to finance development in order to improve people's welfare.

Regional-Owned Enterprise is a business entity whose capital is wholly or partly owned by the region. A Regional-OwnedLLC is an LLC which the capital is divided into shares wholly or at least $51 \%$ (fifty one percent) of the shares are owned by one region. ${ }^{29}$ The position of the regional

${ }^{27}$ Rudhi Prasetya. Kedudukan Mandiri dan Pertanggung jawaban Terbatas dari Perseroan Terbatas (Surabaya: Airlangga University Press, 1983), 30.

28 See Sri Widiyastuti, "Politik Hukum Badan Usaha Milik Daerah (BUMD) dalam Kegiatan Bisnis Untuk Mewujudkan Kesejahteraan Sosial." Law and Justice 4, no. 1 (2019): 12 .

${ }^{29}$ Made Gde Subha Karma Resen \& Yudho Taruno Muryanto. "Implikasi Yuridis Diundangkannya Undang-Undang Nomor 23 Tahun 2014 Tentang Pemerintahan Daerah Terhadap Pengaturan Badan Usaha Milik Daerah di Indonesia." Yustisia Jurnal Hukum 3, no. 3 (2019): 134. 
government in the Regional-Owned LLC is as a shareholder who has rights in the GMS to determine the direction of the Company, including by selecting professional directors to achieve the objectives of the Company in managing tourism destinations. In order to manage Regional-Owned Enterprise professionally and in accordance with the principles of good corporate governance to fulfill the interests of shareholders (Regional-Owned Enterprise owners) and stakeholders (the wider community), an integrated concept is needed. 30

In Article 3 Paragraph (1) of the Government Regulation concerning Regional State-Owned Enterprise, it is stated that the head of regions represents the regional government in the ownership of the separated regional assets in the company, has the position of a shareholder. RegionalOwned LLC must comply with LLC Law. Article 1 of LLC Law defines LLC as a legal entity which is a capital partnership, established based on an agreement, conducting business activities with authorized capital which is entirely divided into shares and meets the requirements stipulated in LLC Law and its implementing regulations. The term 'company' in LLC refers to the method of determining capital in that legal entity which consists of shares while the term 'limited' refers to the limit of liability of the shareholders, which is limited to the nominal value of all the shares owned.

The limited liability of the shareholders at the nominal value of the shares owned is a translation implementation of the principle of limited liability of the shareholders. Limited liability (limitatief aansprakelijheid) is a condition in which shareholders (aandelhouder) of a company are only responsible for the limited number of shares they have in the company. In Article 20 of the Government Regulation No 54 of 2017, this principle states that Regional-Owned Enterprise capital originating from regional capital participation is the limit of regional liability for Regional-Owned Enterprise losses.

Regional-Owned LLC has conferred status as a legal entity. ${ }^{31}$ according to the Indonesian Civil Code (Burgerlijk wetboek / BW) defines legal entity (rechtspersoon) is a group of people who act as if they are a single private body or corporation in the course of law. As a legal entity, Regional-Owned LLC is analogized as a human being who has rights and obligations, owns his property, and can take legal action. This reflects Von Savigny's fictional theory, conceiving that actions of legal entities are considered as human actions, 32 which entails a responsibility for the consequences caused by the actions.

30Yudho Taruno Muryanto \& Djuwiyastuti, "Model Pengelolaan Badan Usaha Milik Daerah (BUMD) Dalam Rangka Mewujudkan Good Corporate Governance," Yustisia Jurnal Hukum 3, no. 1 (2014): 126.

31

Law No. 40 of 2007 concerning Limited Liability Companies, Art. 7 (4) and Government Regulation No. 54 Year 2017 concerning Regional-Owned Enterprise, Art. 4 (5)

${ }^{32}$ Dian Cahyaningrum, "Implikasi Bentuk Hukum BUMD Terhadap Pengelolaan BUMD," Jurnal Imiah Hukum: Negara Hukum Membangun Hukum untuk Keadilan dan Kesejahteraan 9, no. 1 (2018): 65. 
Since LLC is an artificial subject, it requires those who run the company to work in accordance with the aims and objectives of establishing the company. ${ }^{33}$ Regional-Owned LLC is formed to manage regional potential in order to encourage the regional economy and generate profits (profitoriented). The profit resulted $\mathrm{s}$ a source of locally -generated revenue that is needed for development. Considering that the orientation of the RegionalOwned LLC is to gain profit, its directors are required to strive an effort to realize the expected profits. In case directors' policies and actions result in losses, they do not need to worry about being blamed as long as the directors carry out business actions and their management in good faith and full of responsibility and following the aims and objectives of the Regional-Owned LLC as stated in its articles of association. This is the implementation of the fiduciary duties of the directors, namely tasks that are issued legally (by the operation of law) from a fiduciary relationship between the board of directors and the company they lead so that directors must have concern and ability (duty of care and skills), good faith, loyalty, and high degree honesty towards companies.

The head of regions, who represents the region as the majority shareholder in the Regional-Owned LLC, has the authority to appoint its organs, namely directors and commissioners. The board of directors is in charge of managing the Regional-Owned LLC and representing it both inside and outside of the court in accordance with the articles of association. Meanwhile, the commissioners have the duty to supervise and give advice to the directors in carrying out the management activities. The directors and commissioners must be professional persons who meet the qualifications as required in Government Regulation No. 54 of 2017.34 Therefore the selection and appointment of directors and commissioners must be carried out in accordance with the provisions of laws and regulations.

\subsubsection{Regional-Owned Limited Liability Company Can Support the Realization of an Integrated Tourism Management in Bali}

Section 2.1.1 reveals that the obvious managerial problem of tourism in Bali is the existence of a variety of tourism management, both at the provincial level and regencies/city level. This indeed requires a breakthrough. A solution offered in this paper is to utilize the regionalowned enterprise. As discussed in Section 2.2.1, a regional-owned enterprise may be designed as a pioneer in the tourism business sector that is not yet attractive to the private sector and has become a driving force for the economy in the region. The preferable form of this enterprise is a RegionalOwned LLCas discussed in 2.2.3. It is a legal entity that follows the path as

${ }^{33}$ Muhammad Gary Gagarin Akbar \& Deny Guntara, "Perubahan Bentuk Perusahaan Daerah Ke Perseroan Daerah: Perusahaan Daerah Air Minum Karawang," Jurnal Imiah Hukum De'Jure: Kajian Ilmiah Hukum 3, no. 1 (2018): 72.

34 The requirements to become a member of the Commissioner are regulated in Article 38 Government Regulation No. 54 of 2017, while the requirements to become Directors are regulated in Article 58 Government Regulation No. 54 of 2017. 
stipulated in LLC Law but in terms of share, is owned, fully or majority, by regional governments.

Regional-Owned LLC can support the realization of an integrated tourism management that has been expected to be implemented in Bali. Establishing a Regional-Owned LLC that subject to the company law, will strengthen the professionalism in terms of management, compare to the current multi managerial run by each region. Besides, Regional-Owned LLC will also accommodate the participation of the region through the shareholder forum in the company. As previously explained, a region can own all (100\% /one hundred percent) of the shares of the Regional-Owned LLC. ${ }^{35}$ Besides, it is also possible for regions to own shares of at least $51 \%$ (fifty-one percent). This means that other parties can own the RegionalOwned LLC shares, provided that at least 51\% (fifty-one percent) of its shares are owned by one region. Thus, Regional-Owned LLC can be owned by:

1. One local government owns all of the shares.

2. More than one local government, where one local government owns at least $51 \%$ of the shares.

3. One regional government with other parties (non-regional government), in which the local government concerned owns shares of at least $51 \%$.

4. More than one local government with other parties (non-regional government), where one local government has a share of at least $51 \% .36$

Regional-Owned LLC in the tourism Sector can be formed with a combination of 9 Regency/City Governments together with 1 Provincial Government in the form of a Tourism Sector Period.

\section{CONCLUSION}

The rapid development of tourism in Bali has made this sector the main economic pillar in Bali. However, the advancement of the tourism industry in Bali is not followed by equal distribution of tourism development in Bali, this imbalance does not only cover tourism facilities but also includes tourism management. Tourism development has also endangered the preservation of the natural environment. Currently, each regency and city apply different tourist destination management, besides management performed at the provincial level. Therefore, the idea of 'One Island, One Management' is aimed to minimize the gap of tourism development between regencies and city through establishing an integrated tourism management.

Regional-Owned LLC can support the realization of an integrated tourism management in Bali. A Regional-Owned LLC is subject to the

${ }^{35}$ See the exemption for the requirements to establish LLC in Article 7 (7) in Law no. 40 of 2007 concerning Limited Liability Companies.

36 Ibid., 64 
company law. This legal status is expected to strengthen the professionalism of managerial aspects, compare to the multi-regions-based tourism management. The Regional-Owned LLC will also accommodate the region's participation through the shareholder forum in the company.

\section{BIBLIOGRAPHY}

\section{Book}

Middleton, V. \& Hawkins, R. Practical environmental policies in travel and tourism - Part I: The hotel sector, Travel and Tourism Analyst 6, 1993).

Prasetya, Rudhi. Kedudukan Mandiri dan Pertanggungjawaban Terbatas dari Perseroan Terbatas. Surabaya: Airlangga University Press, 1983.

Wheeler, M. Applying ethics to the tourism industry, Business Ethics: A European Review 1 (4), 1992.

\section{Journal Article}

Akbar, Muhammad Gary Gagarin \& Guntara, Deny. "Perubahan Bentuk Perusahaan Daerah Ke Perseroan Daerah: Perusahaan Daerah Air Minum Karawang." Jurnal Ilmiah Hukum De'Jure: Kajian Ilmiah $\begin{array}{lllll}\text { Hukum } 3, & \text { no. } & 1 & \text { 68-78. }\end{array}$ https://doi.org/10.35706/dejure.v3i1.1886

Antara, Made \& Sumarniasih, Made Sri. "Role of Tourism in Economy of Bali and Indonesia" Journal of Tourism and Hospitality Management 5, no. 2 (2017): 34-44. https://doi.org/10.15640/jthm.v5n2a4

Budiasa, I Wayan \& Ambarawati, I Gusti Agung Ayu. "Community based agro-tourism as an innovative integrated farming system development model towards sustainable agriculture and tourism in Bali" Journal of the International Society for Southeast Asian Agricultural Sciences 20, no. 1 (2014): 29-40.

Cahyaningrum, Dian. "Implikasi Bentuk Hukum BUMD Terhadap Pengelolaan BUMD." Jurnal Ilmiah Hukum: Negara Hukum Membangun Hukum untuk Keadilan dan Kesejahteraan 9, no. 1 (2018): 59-78. https://doi.org/10.22212/jnh.v9i1.997

Chevalier, Sylvine Picker \& Budarma, Ketut. "Towards sustainable tourism in Bali: A Western paradigm in the face of Balinese cultural uniqueness" Mondes $d u$ Tourisme, no. 1 (2016): 1-21. https://doi.org/10.4000/tourisme.1187

Damayanti, Ida Ayu Kade Werdika. "Effectiveness of The Implementation of Corporate Social Responsibility By Star Hotels in Nusa Dua Area to Improve the Environmental Quality and Community Welfare." Atlantis Press: Advances in Social Science, Education and Humanities Research 226, (2018): 496-503. https://doi.org/10.2991/icss-18.2018.103

Dewi, I Gusti Ayu Agung Omika. "Culture of Tri Hita Karana on Ease of Use Perception and Use of Accounting Information System" International Journal of Social Sciences and Humanities 2, no. 2 (2018): 77-86. http://dx.doi.org/10.29332/ijssh.v2n2.131

Hassan, Salah. "Determinants of Market Competitiveness in an Environmentally Sustainable Tourism Industry." Journal of Travel 
$\begin{array}{lllll}\text { Research } & 38, & \text { no. } & 3 & \text { (2000): }\end{array}$ https://doi.org/10.1177/004728750003800305

Lathif, Nazaruddin., Wijaya, Mustika Mega., \& Mihradi, Raden Muhammad. "Changes in the Legal Agency Status of the Pakuan Bogor Regional Legal Company in Improving Drinking Water Services in Bogor City based on Government Regulation Number 54 of 2017 Concerning Local Government Owned Enterprises (BUMD)" International Journal of Multicultural and Multireligious Understanding 8, no. 1 (2021): 125133. http://dx.doi.org/10.18415/ijmmu.v8i1.2301

Mudana, I G., Suamba, I B P., Putra, I M A., \& Ardini, N W. "Practices of Bali Tourism Development, Threefolding, and Tri Hita Karana Local Knowledge in New Order Indonesia" Journal of Physics: Conference Series, no. 2 (2017): 1-13. https://doi.org/10.1088/17426596/953/1/012108

Muhammad, Suradji, Irman., Husna, Asmaul. \& Suswaini, Eka. "Reorganisasi Badan Usaha Milik Daerah: Upaya Meningkatan Kemandirian Daerah." Jurnal Ilmu Administrasi: Media Pengembangan Ilmu dan Praktek Administrasi 17, no. 4 (2020): 35-49. https://doi.org/10.31113/jia.v17i1.547

Muryanto, Yudho Taruno \& Djuwiyastuti. "Model Pengelolaan Badan Usaha Milik Daerah (BUMD) Dalam Rangka Mewujudkan Good Corporate Governance." Yustisia Jurnal Hukum 3, no. 1 (2014): 125-134. https://doi.org/10.20961/yustisia.v3i1.10136/

Nasution, Darwin. "Urgency of Local-Owned Enterprises (BUMD) Law as Good Corporate Governance Basis in Indonesia" Atlantis Press: Advances in Social Science, Education and Humanities Research (ASSEHR) 141, (2017): 113-118. https://doi.org/10.2991/icoposdev17.2018 .24

Picard, Michel. "Cultural Tourism in Bali: Cultural Performances as Tourist Attraction" Cornell University Press: Indonesia 49, (1990): 37-74. https://doi.org/10.2307/3351053

Putra, I Nyoman Darma. "Localizing the Global and Globalizing the Local: Opportunities and Challenges in Bali Island Tourism Development" Jurnal Kajian Bali 3, no. 2 (2013): 119-136.

Resen, Made Gde Subha Karma \& Muryanto, Yudho Taruno. "Implikasi Yuridis Diundangkannya Undang-Undang Nomor 23 Tahun 2014 Tentang Pemerintahan Daerah Terhadap Pengaturan Badan Usaha Milik Daerah di Indonesia." Yustisia Jurnal Hukum 3, no. 3 (2019): 127-135. https://doi.org/10.20961/yustisia.v3i3.29560

Sharpley, Richard. "Tourism and Sustainable Development: Exploring the Theoretical Divide." Journal of Sustainable Tourism 8, no 1 (2000): 119. https://doi.org/10.1080/09669580008667346

Sudjana, I Made., Bendesa, I Komang Gde., \& Wiranatha, Agung Suryawan. "Sanur Area Development Strategy Towards Green Tourism Destination" David Publishing: Management Studies 7, no. 5 (2019): 427-434. https://doi.org/10.17265/2328-2185/2019.05.003

Sutawa, Gusti Kade. "Issues on Bali Tourism Development and Community Empowerment to Support Sustainable Tourism Development." 
Procedia Economics and Finance 4, (2012): 413-422. https://doi.org/10.1016/S2212-5671(12)00356-5

Suwardi, Maskun \& Prasetyo, P. Eko. "Efisiensi Teknis Badan Usaha Milik Daerah (BUMD) Bidang Jasa Produksi Provinsi Jawa Tengah.” Jurnal Ekonomi \& Studi Pembangunan 19, no. 1 (2018): 11-20. https://doi.org/10.18196/jesp.19.1.4111

Syam, Fauzi., Elita Rahmi, and Arsyad. "Eksistensi dan Konstruksi Yuridis Badan Usaha Milik Daerah Pasca Undang-Undang Pemerintahan Daerah Tahun 2014." Undang Jurnal Hukum: Fakultas Hukum Universitas Jambi 1, no. 2 (2018): 295-322. https://doi.org/10.22437/ujh.1.2.295-322

Uslu, Abdullah. Alagoz, Gurkan \& Güneş, Erkan. "Socio-cultural, Economic, and Environmental Effects of Tourism from the Point of View of the Local Community." Journal of Tourism and Services 21, no.11 (2020): 1-21. https://doi.org/10.31771/jrtr.2019.50

Widiyastuti, Sri. "Politik Hukum Badan Usaha Milik Daerah (BUMD) dalam Kegiatan Bisnis Untuk Mewujudkan Kesejahteraan Sosial." Jurnal Law and Justice 4, no. 1 (2019): 12-22. https://doi.org/10.23917/laj.v4i1.8050

\section{Law and Regulation of the Republic of Indonesia}

Law No. 40 of 2007 concerning Limited Liability Companies

Law No. 10 of 2009 concerning Tourism

Law No. 23 of 2014 concerning Regional Government

Government Regulation No. 54 of 2017 concerning Regional-Owned Enterprise

Bali Provincial Regulation No. 6 of 2009 concerning Bali Provincial Regional Long-Term Development Plan

Bali Provincial Regulation No. 3 of 2019 concerning the Bali Provincial Regional Medium Term Development Plan Semesta Berencana 20182023

\section{Other Documents}

Badan Pembinaan Hukum Nasional "Pembentukan Otonomi Khusus Bali dan Pengaruhnya bagi Keutuhan NKRI". http://www.bphn.go.id/data/documents/lit-2011-5.pdf. 